\title{
Advanced Digital Technologies for the Conservation and Valorisation of the UNESCO Sacri Monti
}

\author{
Cinzia Tommasi, Cristiana Achille, Daniele Fanzini and Francesco Fassi
}

\begin{abstract}
Information technology touches all the main activities that orbit Cultural Heritage, including management, communication, monitoring and conservation. In particular, advanced digital tools can help the process of preservation, fostering a participatory process connecting diverse experts with various skills and educational backgrounds, and empowering the maintenance activities. The practical example of this statement is its application to the Sacri Monti site. Thanks to its inclusion on the UNESCO World Heritage list, the needs of the site are highlighted in the Periodic Report, a tool useful for monitoring the existing condition of the site. The research presented here attempts to develop a solution for the conservation issue, using advanced technology as a tool for managing the safeguarding activities, creating a product that actively involves users and stakeholders, contributing to the valorisation process.
\end{abstract}

Keywords UNESCO site $\cdot$ Valorisation $\cdot$ Digital $\cdot$ Communication $\cdot$ Survey $\cdot 3 \mathrm{D}$ model $\cdot$ Participatory process $\cdot$ Co-design

\section{Introduction}

The valorisation of Cultural Heritage is an entire process within a structured and territorial vision. The strategic lines dealing with the conservation and preservation of buildings are several. The site is one of the main actions that help this process, and it should be the result of an interdisciplinary vision that connects public institutions, various experts and local communities (Laing 2018). In this framework, the first obstacle to overcome is the communication between many actors, and the use of advanced digital technologies allows for better management of the information at every stage of the project (Della Torre 2014). In order to overcome this issue, valorisation (MiBACT 2019) consists of the activities aimed to promote awareness

C. Tommasi $(\bowtie) \cdot$ C. Achille $\cdot$ D. Fanzini $\cdot$ F. Fassi

Architecture, Built Environment and Construction Engineering-ABC Department,

Politecnico di Milano, Milan, Italy

e-mail: cinzia.tommasi@polimi.it

B. Daniotti et al. (eds.), Digital Transformation of the Design, Construction and Management Processes of the Built Environment, Research for Development, https://doi.org/10.1007/978-3-030-33570-0_34 
of national heritage, and to ensure the best conditions of use and access to that heritage by all members of the public, to stimulate cultural development. Improving the diffusion and the involvement of local communities in heritage awareness can foster identities, strengthen communities and support business and sustainable development.

This premise considers valorisation as knowledge awareness and improvement, and the first step to trigger this kind of process is to collect tangible data and intangible information about the application field, finding a way to use and combine it in a sharable and accessible system. Current research in the field of Cultural Heritage concentrates on the investigation of advanced conservation strategies that also include the possibility of sharing and use of the relative structured information and 3D models (Benatti et al. 2014; Apollonio et al. 2017). One of the methods adopted to achieve this goal is to use a structured web platform (Fassi and Parri 2012). This kind of online system can handle 3D data models, created to contain and support punctual information. They simultaneously respond to the need for storing different types of data (coming from heterogeneous sources) and sharing information between different expert users.

\section{Sacri Monti Application Field}

The research focused on the nine Sacri Monti of Piedmont and Lombardy (Northern Italy), which are holy paths in a beautiful, isolated landscape (Fig. 1). The chapels and the church along the route contain artistic scenes (statues, paintings, etc.) that evoke the theme of the pathway. They have been included in the UNESCO World Heritage list since 2003 (UNESCO 2003). As part of this global institution, they have to maintain the parameters and criteria ${ }^{1}$ (UNESCO 1972; UNESCO 2005) to stay on the list. The Italian Lex $\mathrm{n}^{\circ} 77$ of 2006 (and subsequent updates) identifies the UNESCO sites as points of Italian excellence, representing the country on an international level. It recognises the management plans required from the organisation as tools to ensure the conservation and valorisation of the sites, defining intervention priorities and the implementation methods and the actions for finding public and private resources. The Sacri Monti circuit is subject to the drafting of a 'periodic report', one of the core conservation monitoring mechanisms of the World Heritage Convention.

Every 6 years, the States Parties are invited to submit to the World Heritage Committee a Periodic Report on the application of the World Heritage Convention in their territory. ${ }^{2}$

The Report (UNESCO 2014) is composed of two sections, in the form of a questionnaire, compiled by the World Heritage Site Manager (Sect. 2) and the National

\footnotetext{
${ }^{1}$ Operational Guidelines for Implementation of the World Heritage Convention.

${ }^{2}$ Unesco Periodic reporting https://whc.unesco.org.
} 


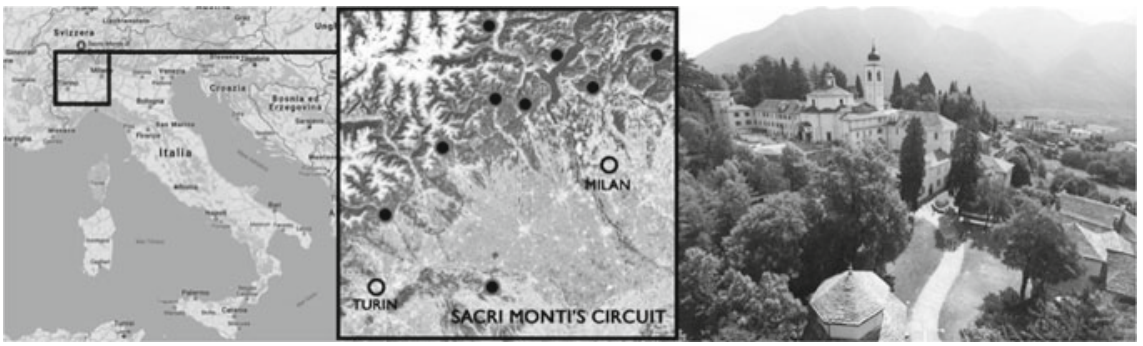

Fig. 1 The Sacri Monti circuit geolocalisation

Focal Point (Sect. 1 and validating Sect. 2): the first lists the State Party and the institutions and groups involved in the preparation of the Report; the second provides information about the primary data of the property and its management.

Thus, the document contains a series of criteria through which to assess the "health status' of the Sacri Monti and as such, is a good starting point to define the needs of the site.

The categories represented in the Periodic Report Second Cycle (2012-2015 for Europe), highlight these main requirements:

- Annual conservation work/action plan.

- Education and awareness programmes.

- Local community and stakeholder engagement.

- Tourism monitoring.

The management needs of the sites required a monitoring programme for improving the understanding of Outstanding Universal Value ${ }^{3}$ and knowledge of the areas. The research activity in progress aims to respond to these needs, contributing to the fulfilment of the Third Cycle of the Periodic Reporting (2019-2024). In particular, this chapter focuses on the management system, proposing a structured methodology for planning and storing conservation activities and supporting interdisciplinary work.

The main steps of the project are outlined below (Tommasi et al. 2019):

- Knowledge phase: Experimentation and integration of different systems and technologies of the 3D survey for a multi-scale representation (architectural and landscape scale);

- Modelling phase: Definition of the workflow from the data (point cloud, bidimensional drawings DWG, etc.) to accurately building the 3D model to support related information; creation of support for the information collected;

\footnotetext{
${ }^{3}$ Outstanding Universal Value (UNESCO 2005, Operational Guidelines) Par. 49. Outstanding universal value means cultural and/or natural significance, which is so exceptional as to transcend national boundaries and to be of common importance for present and future generations of all humanity. As such, the permanent protection of this heritage is of the highest importance to the international community as a whole. The Committee defines the criteria for the registration of properties on the World Heritage List.
} 


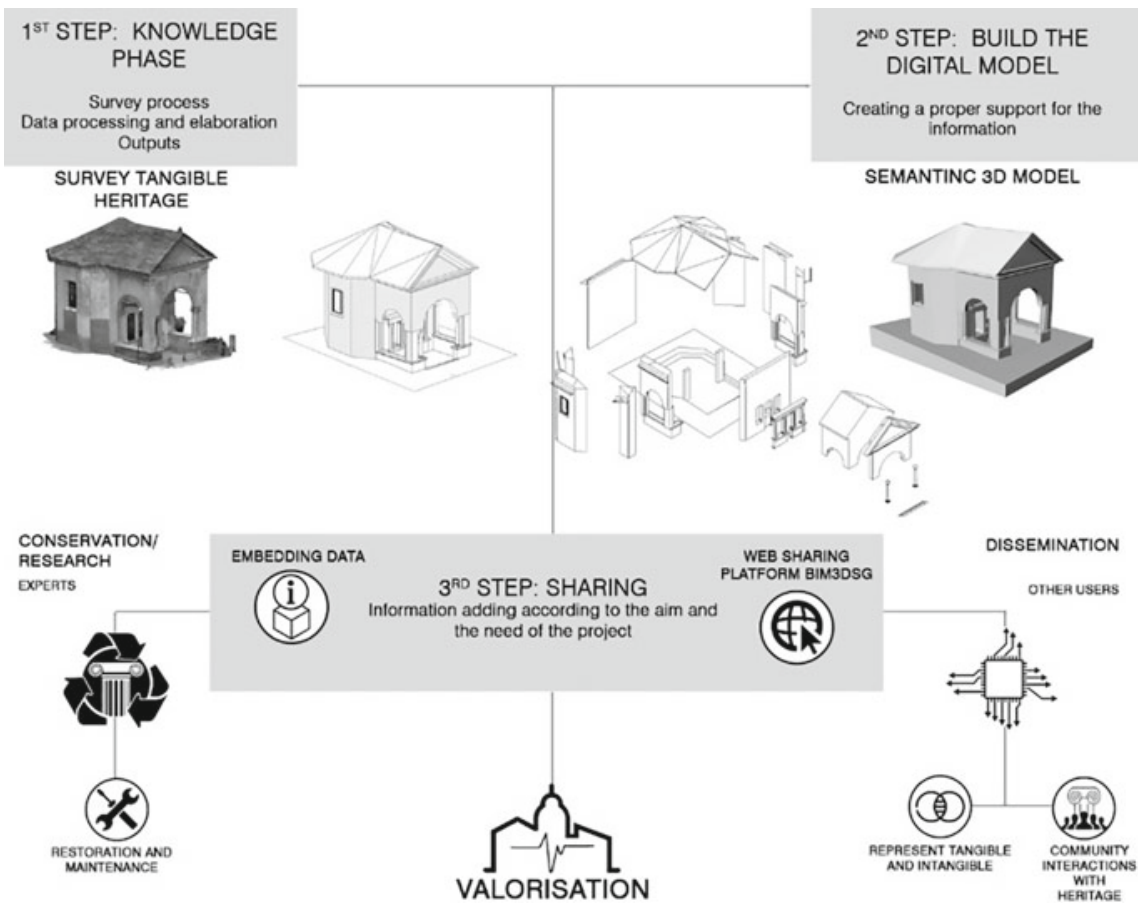

Fig. 2 Workflow from survey data to modelling, web sharing access and final visualisation

- Sharing Phase: Methods and modalities for access to and web sharing of the 3D multi-scale reconstructions and further information from experts with different skills (Fig. 2).

\section{Data Management Through an Online Information System for Conservation}

The first topic addressed is the elaboration of the existing survey data for building 3D models of chapels used as pilots; in this case, the data inserted came from the Ente di Gestione dei Sacri Monti ${ }^{4}$ and the summer school Laboratory of Places 2018 by the Politecnico di Milano (Achille et al. 2018). Starting with the survey data, ${ }^{5}$ which

\footnotetext{
${ }^{4}$ From 2012, the Regional Lex n ${ }^{\circ}$ 19/2009, merged the seven Sacri Monti of Piedemont in the Ente di Gestione dei Sacri Monti, which is a regional management body.

${ }^{5}$ During the Laboratory of Places 2018 six chapels of Sacro Monte di Domodossola were surveyed, the data acquired and inserted in the web system includes: general point cloud of the site coming from Leica Pegasus Backpack, point cloud coming from Leica C10 TLS, photogrammetric point cloud obtained from the integration of UAV and terrestrial photogrammetry. The clouds are georeferenced
} 
consists mostly of bi-dimensional drawings in DWG format and images in RASTER format, the first step is to build a 3D model, which provides information support. The choice of BIM technique ${ }^{6}$ is due to: (i) the increasing implementation of this process in national and international regulations; (ii) the potential that connecting the 3D model with an entire information system offers; (iii) the object-oriented structure that supports the building of a semantic model; (iv) the possibility of managing the whole life cycle of the building.

The criterion for building the model was its description in all the constitutive parts necessary to support the punctual information about conservation and management. The Politecnico's operators and the Ente di Gestione identified the objects to model and the level of detail needed to ensure correct georeferencing of all the information required. Therefore, it was necessary to know and select the data before assignment to the model. In this case, the information was about roof monitoring, humidity, static damage, and restoration information regarding the statues.

Once the BIM model is built, it can serve different purposes as it is possible to export it in many formats. This feature helps the sharing phase to transition from a BIM model that can only be edited by BIM specialists, into an open system, accessible to all kinds of specialist. In assessing the 3D model and the monitoring data available, the primary necessities are: to manage and easily visualise a structured information database, to share the models and their content between experts with different skills and backgrounds and to manage conservation activities, enhance the survey data and the output. The tangible result for these specific needs is the BIM3DSG web platform ${ }^{7}$ which allows for:

- Loading, visualisation and use of 3D models inside an ordinary web browser, selecting the level of detail desired.

- Monitoring the conservation status of Sacri Monti.

- Managing the information system.

- Using the system in portable devices.

- Sharing data among experts with different skill sets and backgrounds.

The benefit of this system is the possibility to shape it according to the needs of the application field. Thanks to teamwork and the bottom-up approach, the result is accurate and tailored to the real needs of the chapels. Within the environment, the three-dimensional objects modelled become categories of real elements, to which different kinds of information is assigned, according to typology: information that

\footnotetext{
using the Leica Pegasus Backpack data as reference. Modelling data: the BIM model of Chapels, georeferenced as point clouds, and divided into all the elements and categories required from the restorers and workers of Enti Gestione Sacri Monti. Conservation information: structural and humidity analyses, decay, 2D drawings, photos, and more.

${ }^{6}$ The models were elaborated with the software Autodesk Revit, as the software guarantees complete compatibility with the DWG drawings of the Ente (coming from Autodesk AutoCAD, same software house), and a very good management of the point clouds, making the modelling phase much easier.

${ }^{7}$ The system was developed starting from the prototype BIM3DSG (3DSurvey - Patent Pending MI2014A002016), an online platform created ad hoc and through the collaboration between the Politecnico di Milano and the final users/consumers.
} 
belongs to the objects, information that changes after a 3D model update and information that varies according to different time thresholds (Fig. 3).

The first operation is the creation of a structured Database (DB), which represents 'the skeleton' of the user interface. Once the fields to be listed were identified, it was necessary to organise them at an IT level, following the BIM3DSG logic of

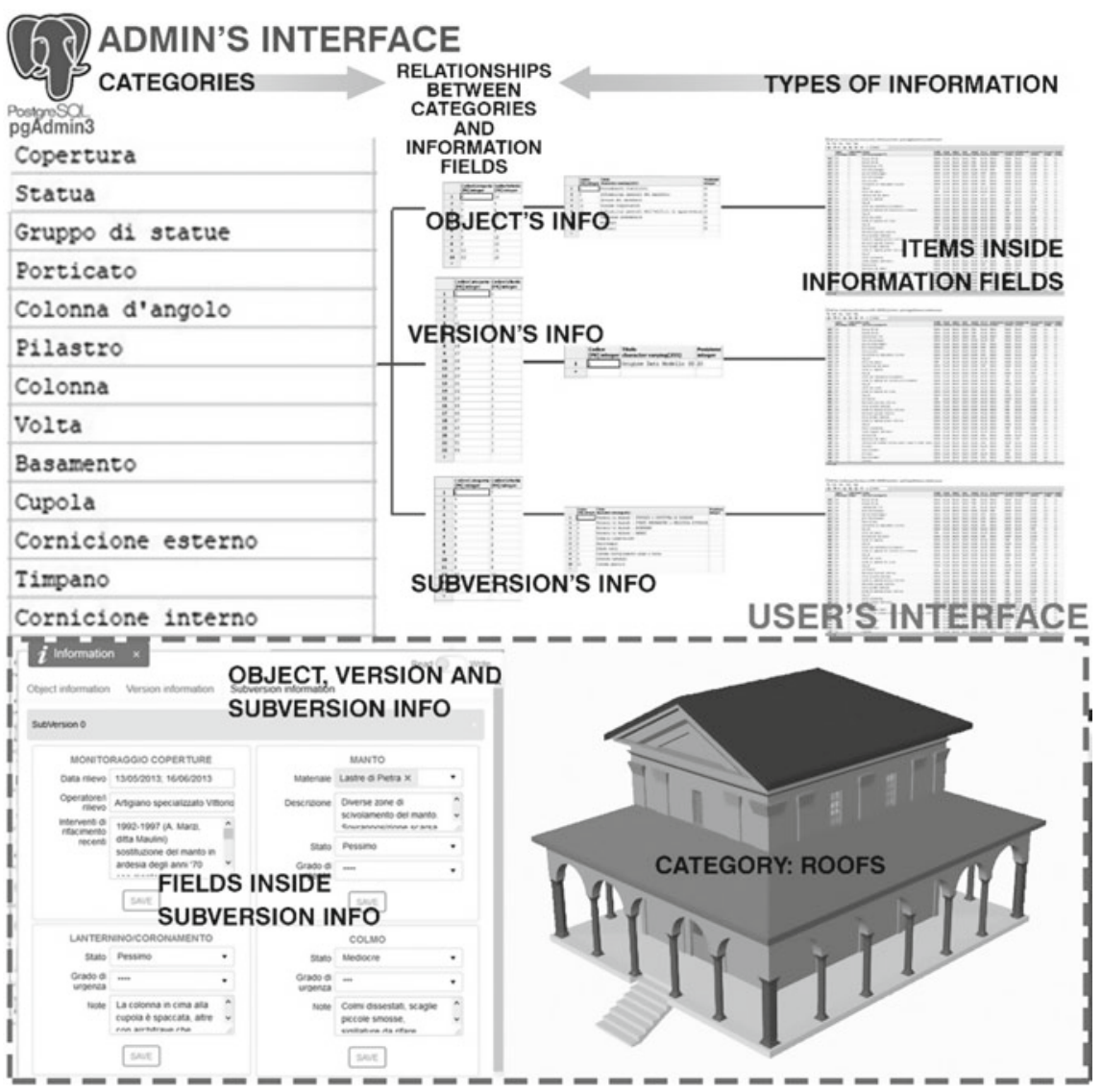

Fig. 3 Structure of the admin system: each 3D element is assigned to a category, and each category has structured information attached. In the lower part, the visualisation of the structure of the database in the user interface 
structure and relationships between pieces of information ${ }^{8}$ (Rechichi et al. 2016). Thus, it was possible to link in a dynamic way the models and the data about the state of conservation and the interventions on the Chapels. This structure is presented in PostgreSQL, a 'free database management system' developed through PgAdmin software.

Moreover, the system allows various data to be saved and stored as digital documents, 3D models, videos, images, etc., and these may be consulted within the web environment. In particular, each model was attached to the original report in the format provided (mainly PDF format).

\section{Contribution of the Research to the Co-design Process}

The Periodic Reporting Questionnaire is the document that ensures the continuity of the exceptional universal value of the $\mathrm{CH}$, providing information on the measures adopted, the actions taken and the state of conservation of the cultural heritage. The previous paragraphs have illustrated the usefulness of having a 3D model to support the conservation and monitoring activities, but the same technologies could also be used to increase the awareness of citizens and their active participation in defining the strategies and methods for the development of the area.

The 'experimentation' of cultural resource consumption through the involvement of creative operators (Fanzini and Rotaru 2015; Fanzini 2017) represents a sector of undoubted centrality and relevance for improving the quality of cultural consumption and at the same time triggering a new economy (Della Torre 2015). This formula implies the transition from a passive cultural fruition model to one in which the user actively participates, co-producing individual experiences.

Citizens' involvement is increasingly acknowledged as an important success factor able to contribute to all phases of the processes connected to the protection of world cultural heritage, from the initial start-up stages to the subsequent development and actual implementation. The terms co-design and user-centred design (stressing the involvement of endusers from the early stages of the process-fuzzy front end), have

${ }^{8}$ The system's architecture includes:

- The categories that represent the 3D components division, and refer to classes of real elements;

- The information that is divided into three classes: object info: the data that does not change in time, version info: the 3D model changes over time, and subversion info: the 3D model does not change over time, but the information related to it is updated, allowing operations to be traced and inspections already made or in progress in the buildings, handling their life-cycle and planning the events over time.

Each class of information has different macro fields, and each macro field has specific "boxes" inside, defining the name and typology of fields (text, date, multiple choice, and more).

The classes of information are connected to the categories through relationships that relate the number of the macro field to the number of categories. The structure of the database has a user interface inside the web browser, e.g. Mozilla firefox. 
been introduced to describe this particular endeavour. The evolution of user involvement models, from the participatory formulas to the real co-design, has changed the role of professional designers, and also that of the project users, establishing new creative domains.

As noted by Jannack et al. (2015), the real challenge for the future co-design environment is to enable communication and collaboration between large numbers of experienced citizens and professionals, ensuring a more creative, targeted and secure design process for projects of public interest. In other words, there is a need for collaborative tools and environments that allow creative professionals to capitalise on the ingenuity of crowds, to follow opinions, feelings, values and exploit widespread intelligence. The Building Information Modelling (BIM) turned out to be an effective expert instrument in similar cases. The intermediation of information exchange from the computer model of the real-life building enables a better understanding of the planned intervention, opening the design process to different stakeholders not necessarily familiar with specialised representation conventions. As part of the proposal, BIM is, therefore, the enabling technology that could be used to connect different information, from the conscious and compelling expression of the client's needs, to the broad and operational sharing of the project, also fostering the possibility to access and use diffuse data (Fig. 4).

In addition to the responsible use of technologies, special attention is needed for the configuration of methods and processes for the creative involvement of users. In other words, computer skills have to be combined with the in-depth knowledge of collaborative design practices that can specifically involve the original contribution of users.

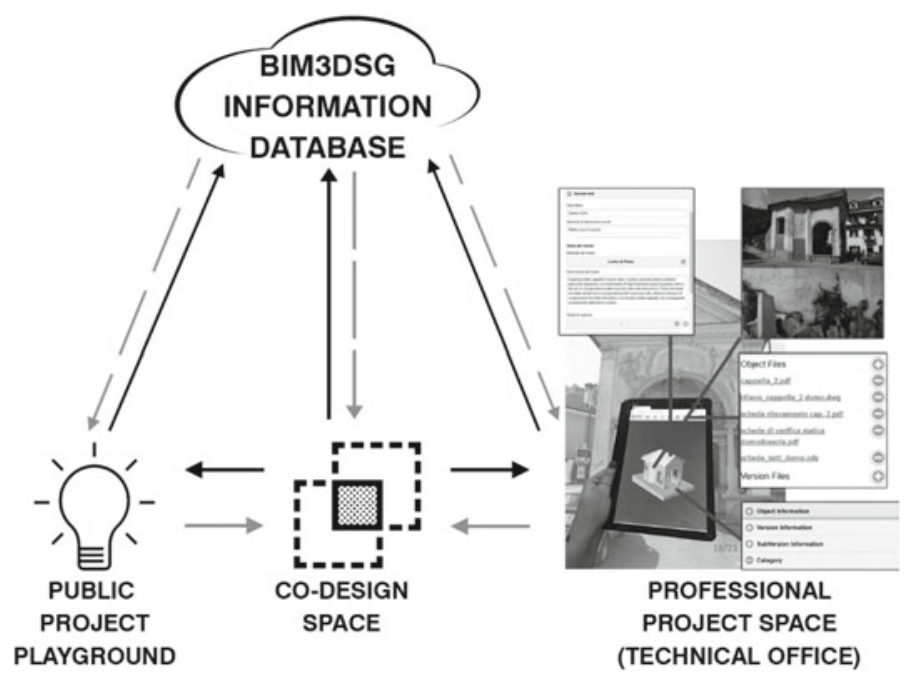

Fig. 4 Re-elaboration of the co-design environment (Jannack et al. 2015) 
In this sense, the BIM 3D model could contribute to the realisation of interactive systems that facilitate public participation by anticipating problems and allowing creative interaction between experts, local communities and the various stakeholders.

\section{Conclusion}

In conclusion, the research aims to show how it is possible to build a valid tool for the conservation and monitoring activities of $\mathrm{CH}$, following national and international legislation and the specific needs of the application field. In particular, it will broaden the criteria to build a semantic 3D model that will link a database of information, specifying the logic and the specifications behind it.

In the same way, it will show how to build a database collaborating with local institutions and experts, following the real needs of the site. The benefit is that this kind of tools gives multidisciplinary works and projects a shared environment for storing and viewing a variety of data. They can help both to implement conservation activities and be open to the public. The result will help to update a section of the UNESCO Periodic Report and will contribute to shaping 'standard' best practices to monitor and safeguard all similar case studies.

Acknowledgements The authors would like to thank the Ente di Gestione Sacri Monti, managers of the seven Sacri Monti of Piedmont. They are actively collaborating with the 3D Survey Group in the ABC Department of the Politecnico di Milano, providing DWG and PDF materials and are involved in the decision-making process of the valorisation strategy.

\section{References}

Achille C, Fassi F, Mandelli A, Fiorillo F (2018) Surveying cultural heritage: summer school for conservation activities. Appl Geomatics 10(4):579-592. https://doi.org/10.1007/s12518-018$0225-3$

Apollonio FI, Basilissi V, Callieri M, Dellepiane M, Gaiani M, Ponchio F, Rizzo F, Rubino AR, Scopigno R, Sobrà G (2017) A 3D-centered information system for the documentation of a complex restoration intervention. J Cult Herit 29:89-99. https://doi.org/10.1016/j.culher.2017. 07.010

Benatti E, Borgarino MP, Della Torre S (2014) PLANET beni architettonici. Uno strumento per la conservazione programmata del patrimonio storico-architettonico. In: ICT per il miglioramento del processo consevrativo. Ed Nardini, Milano, Italy, pp 13-31

Della Torre S (2014) Oltre il restauro, oltre la manutenzione. Keynote lecture in La strategia della Conservazione programmata. Dalla progettazione alle attività di valutazione degli impatti. Ed. Nardni, Milano, Italy, pp 1-10

Della Torre S (2015) Lezioni imparate sul capo dei distretti culturali. In: Il Capitale Culturale: studies on the value of cultural heritage 03, 61-73. https://doi.org/10.13138/2039-2362/1175

Ente di Gestione dei Sacri Monti. https://www.sacri-monti.com/. Accessed 13 May 2019

Fanzini D (2017) Tecnologie e processi per il progetto del paesaggio. Reti e modelli distrettuali, 1st edn, Maggioli Editore, Santarcangelo di Romagna, IT 
Fanzini D, Rotaru I (2015) Processi inclusivi e project anticipation per la rigenerazione delle città e dei territori. Techne 10:102-109. https://doi.org/10.13128/Techne-17506

Fassi F, Parri S (2012) Complex Architecture in 3D: from survey to web. Int J Herit Digit Era 1:379-398

Jannack A, Munster S, Noenning JR (2015) Enabling massive participation: blueprint for a collaborative urban design environment. In: Proceedings of IFKAD 2015, publisher: international forum on knowledge asset dynamics, editors: Giovanni Schiuma, 2363-2380

ICOMOS International Council on Monuments and Sites. Retrieved from: https://www.icomos. org/. Accessed 18 March 2019

Laing R (2018) Digital participation and collaboration in architectural design, 1st edn. Routledge, Oxon, UK

Ministero per I Beni e le Attività Culturali - MiBACT. http://www.beniculturali.it/mibac/export/ MiBAC/index.html. Accessed 14 March 2019

Rechichi F, Mandelli A, Achille C, Fassi F (2016) Sharing high-resolution models and information on web: The web module of BIM3DSG system. In: International archives of the photogrammetry, remote sensing and spatial information sciences, vol XL-B5, pp 703-710. https://doi.org/10.5194/ isprs-archives-XLI-B5-703-2016

Regione Piemonte e Lombardia (2015) Sacri Monti of Piedemont and Lombardy. Ed. Sagep, Genova, Italy

SACHER Smart Architecture for Cultural Heritage in Emilia-Romagna (POR FESR 2014-2020). http://www.sacherproject.com/. Accessed 2 April 2019

SICaRweb - Sistema informativo per I cantieri di restauro. http://sicar.beniculturali.it/. Accessed 2 April 2019

Tommasi C, Fiorillo F, Jiménez Fernández-Palacios B, Achille C (2019) Access and web-sharing of 3D digital documentation of environmental and architectural heritage. In: International archives of the photogrammetry, remote sensing and spatial information sciences, vol XLII-2/W9, pp 707-714. https://doi.org/10.5194/isprs-archives-xlii-2-w9-707-2019

Standards and Laws

Codice dei Beni Culturali e del paesaggio (2004, January 22) Decreto Legislativo 22 gennaio 2004, n. 42. Retrieved from https://www.beniculturali.it/mibac/multimedia/MiBAC/documents/ 1226395624032_Codice2004.pdf

Lex $n^{\circ} 77 / 2006$ - Misure speciali di tutela e fruizione dei siti e degli elementi italiani di interesse culturale, paesaggistico, e ambientale, inseriti nella lista del patrimonio mondiale, posti sotto la tutela UNESCO

UNESCO (1972, November 21) Convention Concerning the Protection of the World Cultural and Natural Heritage. Retrieved from https://whc.unesco.org/en/conventiontext/

UNESCO (2003) Document of Sacri Monti's Nomination. Retrieved from https://whc.unesco.org/ list/1068/docs/

UNESCO (2005, revised version 2017) The Operational Guidelines for the Implementation of the World Heritage Convention. Retrieved from https://whc.unesco.org/en/guidelines/

UNESCO (2014) Periodic Report, Second Cycle. Retrieved from https://whc.unesco.org/list/1068/ docs/ 
Open Access This chapter is licensed under the terms of the Creative Commons Attribution 4.0 International License (http://creativecommons.org/licenses/by/4.0/), which permits use, sharing, adaptation, distribution and reproduction in any medium or format, as long as you give appropriate credit to the original author(s) and the source, provide a link to the Creative Commons license and indicate if changes were made.

The images or other third party material in this chapter are included in the chapter's Creative Commons license, unless indicated otherwise in a credit line to the material. If material is not included in the chapter's Creative Commons license and your intended use is not permitted by statutory regulation or exceeds the permitted use, you will need to obtain permission directly from the copyright holder.

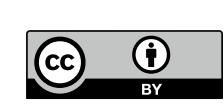

